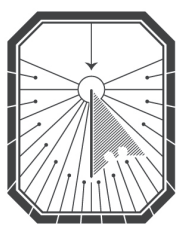

KYIV-MOHYLA

LAW \& POLITICS JOURNAL

KYIV-MOHYLA SCHOLARLY PEER-REVIEWED JOURNALS

Professional Peacemakers in Ukraine: Mediators and Dialogue Facilitators Before and After 2014

Author(s): Tatiana Kyselova

Source: Kyiv-Mohyla Law and Politics Journal 3 (2017): 117-136

Published by: National University of Kyiv-Mohyla Academy

http://kmlpj.ukma.edu.ua/ 


\title{
Professional Peacemakers in Ukraine: Mediators and Dialogue Facilitators Before and After 2014
}

\author{
Tatiana Kyselova \\ National University of Kyiv-Mohyla Academy; \\ Faculty of Law
}

\begin{abstract}
Based on the findings of qualitative empirical study, this article reveals that, in contrast to most violent conflicts in the world, the Ukrainian context is distinguished by the presence of a selforganized, self-aware and skilled local professional communities of mediators and dialogue facilitators. The article analyses each professional community and concludes that Ukrainian mediators and dialogue facilitators are capable to serve as independent actors in peacebuilding process, guiding their international colleagues and the government as for the best practices of mediation and dialogue. At the same time, both communities still experience pains of professional growth such as making choices between core methods and societal roles and they need external support. Additionally, the 2014 crisis has brought some opportunities concerning increased funding for mediation and dialogue, and the top-down pressure of the international community for greater use of these tools. These opportunities have, in turn, triggered some challenges such as an increased competition for funding and ideological tensions between "the peacemakers" and the other groups of Ukrainian civil society inspired by the military discourse.
\end{abstract}

Key Words: mediation, dialogue facilitation, civil society in peacebuilding, conflict resolution, Ukraine.

\section{(2)}

\section{Introduction}

The Euromaidan and the armed conflict in Eastern Ukraine prompted near immediate reaction of international community in terms of supporting civil society peacebuilding, reconciliation, and dialogue initiatives. Ukrainian NGOs received first grants for dialogue and peacebuilding activities as early as 2014. Since that time the international community has supported numerous other mediation and dialogue initiatives throughout the country with a specific focus on civil society and the conflict-affected areas in Eastern Ukraine.

Efforts to enhance the role of civil society in peacebuilding are rooted in practice wisdom and research findings that civil society is capable of increasing the likelihood of peace agreements being reached and implemented. The proposition that civil society is indispensable in peace processes at all levels has already become a truism in conflict resolution and peace studies, resulting in the so-called multi-track approach with a special emphasis on the role of people- 
to-people diplomacy. ${ }^{1}$ Unsurprisingly, this approach has also been applied in Ukraine based on the experience from other armed conflicts, primarily in developing world.

However, this article suggests that experience of civil society peacebuilding that derives from the context of developing countries in Africa or Asia is not directly applicable to Ukraine. It reveals that, among other context-specific factors, presence, capacities and peacebuilding potential of local professional peacemakers - mediators and dialogue facilitators - distinguish Ukrainian conflict from other contexts. Apparently, international community and foreign researchers have not fully appreciated this role, at least in the beginning of the crisis. For example, those few academic and policy researchers who have analyzed civil society peacebuilding in Ukraine, had either omitted analysis of mediators and facilitators as independent actors entirely ${ }^{2}$ or mentioned their projects as general civil society projects. ${ }^{3}$ This article is a first attempt to attract attention of international scholarly and policy community to this phenomenon. It suggests that mediators and dialogues facilitators should be treated as independent actors that drive peacebuilding processes in Ukraine while constituting an integral part of civil society by any definition.

In a wide sense, civil society includes "professional associations such as doctors and lawyers", and by the same token mediators and dialogue facilitators. ${ }^{4}$ Even if defined narrowly as non-governmental organizations, civil society still embraces Ukrainian mediators and dialogue facilitators because their professional organizations are registered as NGOs according to Ukrainian legislation. At the same time, professional communities of mediators and dialogue facilitators cannot be completely equated to NGOs because they possess distinct professional identities, ideologies, and strategies aimed at becoming stand-alone self-regulated professions. Yet, they

Thania Paffenholz, "International Peacebuilding Goes Local: Analysing Lederach's Conflict Transformation Theory and Its Ambivalent Encounter with 20 Years of Practice," Peacebuilding 2.1 (2014).

Roxana Cristescu and Denis Matveev, The Challenge of Inclusiveness in the Peace Processes in Ukraine (Civil Society Dialogue Network, 2017); Global Protection Cluster, Peacebuilding and Reconciliation in Ukraine: Guidance Note, (2016), accessed December 20, 2017, http://www. globalprotectioncluster.org/_assets/files/field_protection_clusters/Ukraine/thematic-updates/ peacebuilding_reconciliation_guidance_note_en.pdf.

For example, according to the OSCE SMM study "the best known examples" of "civil society organizations' own contribution to dialogue efforts" include dialogue projects of the Odesa Regional Mediation Group and Ukrainian Center for Non-violent Communication and Conciliation "Dignity Space." In fact, both organizations are the established members of the professional community. See Special Monitoring Mission Organization for Security and Co-operation in Europe, Civil Society in the Ukrainian Crisis: Thematic Report 8 (2015), accessed December 20, 2017, http://www.osce. org/ukraine-smm/141046?download=true. In a similar vein, the OSCE Study on Insider Mediation, reported Inna Tereschenko as an insider mediator, but in fact she is the head of the Odesa Regional Mediation Group and the founding "mother" of professional mediation community in Ukraine. See Mir Mubashir, Engjellushe Morina, and Luxshi Vimalarajah, OSCE Support to Insider Mediation: Strenghtening Mediation Capacities, Networking and Complementarity (OSCE, 2016). Thomas Carothers and William Barndt, "Civil Society," Foreign Policy 117 (2000): 19. 
are still very young professional communities that are in the process of self-establishment and professional growth and currently lack financial resources. Given this initial stage of development, their capacities should not be overestimated and adequately supported. Understanding these specifics will allow international donor community to formulate proper strategies and to increase efficiency of their peacebuilding aid to Ukraine.

Thus, the aim of this article is twofold. The first aim is to draw the attention of researchers, policy-makers, international organizations and donors to the role of Ukrainian professional communities of mediators and facilitators by offering analysis of their main characteristics, professional identities, ideologies and societal roles. The second aim is to highlight challenges and opportunities that both professional communities face as consequences of the Euromaidan and armed conflict in Eastern Ukraine after 2014.

To advance these aims, the first and the second parts of the article survey professional community of mediators and dialogue facilitators from a civil society perspective. The third part contrasts core methods of mediation and dialogue facilitation as foundations for professional identities of these communities. The fourth part compares ideologies of "society transformation" and "service provision" within both communities. The fifth part offers analysis of the most important challenges and opportunities of the 2014 crisis that both professional communities are currently confronted with. Conclusion offers summary of the findings and remarks regarding further strategies of international community to fully utilize the potential of Ukrainian "professional peacemakers" in peacebuilding efforts in Ukraine.

The article presents findings of a qualitative empirical study which was conducted in May - June 2016 and January 2017 in Kyiv, Odesa, Lviv and Kramatorsk, and consisted of five focus-group discussions with 35 participants and 63 in-depth interviews with mediators, dialogue facilitators, lawyers, judges, local and central government officials, business people and civil society activists. ${ }^{5}$ The sampling initially relied on the information about Ukrainian mediators and dialogue facilitators from the database of the National Association of Mediators of Ukraine, and later on the snowball sampling technique. The sample followed the logic of the most critical case design and aimed at the highest possible degree of variability of the answers. Interviews and focusgroup discussions have been transcribed and analyzed through NVivo software for qualitative analysis of information. Empirical data from the fieldwork was supplemented by information from Internet sources and analysis of the policy documents of Ukrainian government, mediators and dialogue facilitators.

\section{The Professional Community of Mediators}

Mediators are professionals who are trained to mediate disputes and to render mediation services to individuals, businesses and governmental agencies in multiple settings - community, schools, business, state welfare agencies, courts and many others. Mediation refers to a structured dispute resolution process "whereby two or more parties to a dispute attempt by themselves, on 
a voluntary basis, to reach an agreement on the settlement of their dispute with the assistance of a mediator." ${ }^{6}$ In its modern form, mediation originated in the US where it was supported by and integrated within the judiciary. ${ }^{7}$ Since that time mediation has spread around the world with amazing speed. ${ }^{8}$

The first attempts to introduce institutionalized mediation in Ukraine date back to late Soviet times. The dissolution of the Soviet Union was accompanied by a massive wave of strikes in the Donbas region. In the late 1980s a group of Donetsk psychologists developed contacts with US mediators and conducted first Soviet-American seminars on peacebuilding and conflict resolution in the Donetsk and Luhansk regions. This mission prompted Donetsk Psychological Center to ally itself with the US NGO Search for Common Ground to initiate the first mediation center in Ukraine in 1994. This initiative eventually resulted in eight mediation centers set up all over Ukraine and supported by grants from international donors. One of the most active mediation centers in this network - Odesa Regional Mediation Group - claimed to have mediated the first case referred from the courts as early as in $1997 .{ }^{9}$

By the end of the gos the focus of mediation activity moved to Kyiv, where the Ukrainian Center for Common Ground (UCCG) was registered in 2001 and became active in penal mediation, restorative justice, community building, and school mediation. The UCCG has created its own network of 15 partner Ukrainian NGOs and was reorganized into the Institute of Peace and Common Ground in 2012. ${ }^{10}$ In 2008, the International Finance Corporation offered a seed grant to set up a Ukrainian Mediation Center at Kyiv-Mohyla Business School." Apart from these organizations, around a dozen local mediation NGOs were registered in Ukraine. ${ }^{12}$ These organizations made an effort to coordinate their strategies and to draft mediation law through the National Association of Mediators of Ukraine (NAMU). NAMU remains the only nation-wide umbrella organization of mediators that seeks to institutionalize mediation and to represent collective interests of mediators in Ukraine. ${ }^{13}$

6 Directive 2008/52/EC of the European Parliament and of the Council of 21 May 2008 "On Certain Aspects of Cross-border Mediation in Civil and Commercial Matters", Article 3. Lon L. Fuller, "Mediation - Its Forms and Functions," South California Law Review 44 (1971); Carrie Menkel-Meadow, “Mothers and Fathers of Invention: The Intellectual Founders of Adr," Ohio State Journal on Dispute Resolution 16 (2000).

8 Sally Engle Merry, "Moving Beyound Ideology Critique to the Analysis of Practice," Law \& Social Inquiry 27.3 (2002).

9 Odesa Regional Mediation Group, Facebook, December 24, 2017, https://www.facebook.com/ OdessaGroupMediation/. Ukrainian Institute for Peace and Common Ground, http://ipcg.org.ua/en/ (Ukrainian Center for Common Ground, http://www.uccg.org.ua/). Ukrainian Mediation Center, http://ukrmediation.com.ua/en/.

12 For the detailed description of most active mediation organizations, See Tatiana Kyselova, "Mediation Organizations in Ukraine: Short Guide 2017," accessed December 20, 2017, https://papers. ssrn.com/abstract $=3012496$. 
The exact number of members of the mediation community is hard to ascertain. NAMU, which is the only membership-based organization at the time of writing, consists of more than 110 members. The membership of other organizations remains fluid. Judging by annual national congresses, the active community consists of several hundred people, although only few of them are involved in mediation on a full-time basis or make their living as mediators. Interviewees in this study estimated that more than 3,00o Ukrainians took various professional training courses from 24 to 220 hours in length and obtained certificates from mediation training centers in $1997-2017 \cdot \cdot^{14}$

From the mid-199os until now, the activity of the mediation community was focused on the institutionalization of mediation in Ukraine, including public awareness campaigns about mediation in mass media; professional training and certification programs; mediation awareness-raising events; the design and practical implementation of peer-mediation programs in schools as well as mediation schemes in penal matters, commercial, family, employment, tax and administrative disputes; strategic alliance-building with stakeholders in mediation; the incorporation of mediation into the University curriculum; the standardization and quality control of mediation training and mediation practice within the community. Mediators were particularly successful in the development of training programs in basic mediation skills, family mediation, mediation competence for managers, interest-based negotiations, etc. At the time of writing, there were at least three training centers in Kyiv, and several centers in Lviv, Odesa, and Kharkiv regions. Finally, few civil society groups or even established professions can be proud of having passed a statute that legitimizes and regulates their activity. Since 2010, mediation community has developed and registered ten drafts of mediation law with Parliament; in November 2016, Parliament voted on the first reading of one of the drafts. ${ }^{15}$ In 2017, NAMU has finally adopted the Code of Ethics of Mediators that was jointly drafted by many mediation organizations and mediators in Ukraine.

Thus, a lot of resources have been invested into formation of mediators as a professional community. Nevertheless, these efforts have not yet triggered noticeable nation-wide demand in mediation services, and Ukrainian mediators remain "professionals without clients" as in many other European countries. ${ }^{16}$ Therefore, raising public awareness and popular demand for mediation services remain major challenges for Ukrainian mediators from a professional perspective.

14 Interviews with Ukrainian mediator and founder of the training programs, Kyiv, 17 June 2016.

15 The Draft Law on Mediation No. 3665, 17 December 2015, (hereinafter — “The Draft Law on Mediation No. 3665"), accessed December 20, 2017, http://w1.c1.rada.gov.ua/pls/zweb2/ webproc4_1?pf3511=57463.

16 G De Palo et al., "Rebooting the Mediation Directive: Assessing the Limited Impact of Its Implementation and Proposing Measures to Increase the Number of Mediations in the EU," (Brussels: DG for Internal Policies, 2014); Carrie Menkel-Meadow, "Variations in the Uptake of and Resistance to Mediation Outside of the United States," in Contemporary Issues in International Arbitration and Mediation: The Fordham Papers 2014, ed. Arthur Rovine (Leiden and Boston: Brill, 2015). 


\section{The Professional Community of Dialogue Facilitators}

Dialogue facilitators are professionals who are trained to facilitate intergroup dialogues as a part of peacebuilding efforts within violent socio-political conflicts. However, in contrast to mediation, dialogue and dialogue facilitation remain ambiguous terms, because conflict resolution and transformation is a constantly evolving practice that relies on multiple methodologies (discussed in more details in the next section).

In contrast to mediators, who began constructing their history as a professional community since the late 199os, dialogue facilitators in Ukraine were actually "born" in response to the Euromaidan and armed conflict in Eastern Ukraine. Although some professionals claim that they have been practicing dialogue facilitation in Ukraine since the early 199os, they admit that dialogue facilitation received a true impetus and facilitators became visible as a distinct professional community only after 2014 when Ukraine experienced a massive wave of donor aid aimed at peacebuilding. ${ }^{17}$ Therefore, dialogue facilitators had to simultaneously establish their professional identities and respond to the challenges of the 2014 crisis.

Given assorted methodologies and their possibility to be applied in varied settings, dialogue facilitation initiatives are diverse. Already during the Euromaidan protests in 20132014, mediators, facilitators and NGO activists conducted dialogue sessions among protesters and police. These were spontaneous sessions between various groups at the Kyiv Euromaidan or more organized meetings, as for example in Kharkiv, where protesters got a chance to talk to police through professional mediators within organized sessions at local police stations. ${ }^{18}$ In the immediate aftermath of Euromaidan, dialogues were conducted between officers of the Berkut riot police and Maidan protesters and resulted in the establishment of the Ukrainian Center for Non-Violent Communication and Conciliation "Dignity Space". ${ }^{19}$ Special dialogue initiatives were implemented in Odesa in the aftermath of the violent clashes between groups of opposing political orientation in May 2014. ${ }^{20}$

After 2015, when international donors initiated targeted grant support, dialogue moved on to tackle more technical issues such as the problems of internally displaced persons (IDPs), coordination between local government and civil society within decentralization, health care, education, and other reforms involving central and local government, local communities, internally displaced persons, ATO (Anti-Terrorist Operation) veterans, national minorities, and

17 Focus-group discussion with Ukrainian dialogue facilitators, Kyiv, 1 June 2016. See also UK Conflict Pool Peacebuilding Projects in Ukraine, accessed December 20, 2017, https://www.gov.uk/ government/publications/conflict-prevention-pool-work-in-ukraine.

18 Interview with Ukrainian mediator, Kyiv, April 26, 2016.

19 Ukrainian Center for Non-Violent Communication and Conciliation "Dignity Space", https://www. facebook.com/prostir.hidnosti/ It is currently training a new cohort of dialogue facilitators — "peace engineers" https://peaceengineers.com/.

20 The project "The Common House: Supporting and Broadening Dialogue Processes in Odesa" by the Berlin Center for Integrative Mediation http://www.cssp-mediation.org/, Inmedio http://www. inmedio.de/en/, and the Center for Peace Mediation http://www.peacemediation.de/index.shtml in cooperation with the Odesa Regional Mediation Group. 
other groups of population. ${ }^{21}$ Other types of dialogues remain few (so-called "existential" or "identity-based" dialogues, cross-contact-line dialogues involving people from the territories not controlled by the Ukrainian government; ${ }^{22}$ dialogues involving Russian civil society). ${ }^{23}$

To estimate how large the professional community of dialogue facilitators is, two research reports - by Norwegian ${ }^{24}$ and Ukrainian ${ }^{25}$ researchers - have identified around 20 organizations and initiatives on dialogue in Ukraine in 2014-2015. In the summer of 2017, the Ukraine Dialogue Support Platform offered information about 24 Ukrainian NGOs active in dialogue facilitation in Kyiv, Lviv, Kharkiv, Donetsk oblast, Dnipro, Kryvyi Rih, Kherson, Kremenchuk and other places. ${ }^{26}$ Additionally, this research identified around 30 international organizations active in peacebuilding and conflict resolution that have entered Ukraine after 2014 with various projects on peace mediation, dialogue facilitation, and peacebuilding, or plan to work in Ukraine. ${ }^{27}$

This crowded field of dialogue facilitation obviously required some coordination from the outset. Therefore, by mid-2015 the Brussels-based MediatEUr organization and the UNDP launched the internet Ukraine Dialogue Support Platform. ${ }^{28}$ At the moment, the OSCE Project Coordinator's office in Ukraine (OSCE PCU) coordinates and supports professional development and capacity building of dialogue facilitators. In 2014-2017, in partnership with the National Association of Mediators, the OSCE PCU established a pool of Ukrainian mediators and

21 Various types of dialogues currently taking place in Ukraine, their patterns and the resulting risks were analyzed by the Policy Paper which is another outcome of this research project. See, Tatiana Kyselova and Julia von Dobeneck, "Track III Dialogues in Ukraine: Major Patterns and Resulting Risks," 2017, accessed December 20, 2017, http://www.peacemediation.de/uploads/7/3/9/1/73911539/ track_iii_dialogue_ukraine_policy_paper_cpm_kma.pdf. Donbass Dialogue conducts on-line dialogues that involve people from the territories not controlled by the Ukrainian government, http://www.donbassdialog.org.ua/p/about.html.

23 The project by Swisspeace brought civil society activists from Russia, Ukraine and so-called LNR/ DNR to dialogue sessions in Istanbul, Turkey in 2014, https://soundcloud.com/robertboschstiftung/ cecile-druey.

24 Agder Research Project, Norway, accessed December 20, 2017, http://dialogue-ukraine.org/.

25 Mapping of Dialogue Initiatives to Resolve the Conflict in Ukraine, (Kyiv: International Center for Policy Studies, 2015), accessed December 20, 2017, http://icps.com.ua/assets/uploads/files/mapping of_dialogue_initiatives_eng_.pdf.

26 Ukraine Dialogue Support Platform, http://ukraine.dialoguesupport.org.

27 Center for Humanitarian Dialogue, Crisis Management Initiative, MediatEUr, Swisspeace, Nansen Center for Peace and Dialogue, Forum Civil Peace Service (ForumZFD), Center for Security Studies ETH Zurich, CSSP — Berlin Center for Integrative Mediation, Center for Peace Mediation, Inmedio, International Crisis Group, International Alert, PAX for Peace, Peaceful Change Initiative, Relational Peacebuilding Initiatives, CRISP Berlin, Peace Action Training and Research Institute Romania (PATRIR), Global Partnership for Prevention of Armed Conflicts (GPPAC), Institute for Conflict Transformation and Peacebuilding, UN Women, OWEN (Women's Initiative for Peace in Donbas/s), Women NGO “La Strada”, Berghof Foundation, US Institute for Peace.

28 Ukraine Dialogue Support Platform, http://ukraine.dialoguesupport.org (the project was discontinued in summer 2016). 
facilitators who are called to facilitate dialogue sessions for OSCE supported events; conducted annual international conferences on dialogue facilitation; initiated regular donor coordination meetings; launched the online and face-to-face training courses in dialogue facilitation and organization of dialogues. ${ }^{29}$ Nevertheless, coordination of many dialogue projects and the impact of dialogue remain the most pressing challenges for Ukrainian dialogue facilitators.

\section{Professional Identities of Mediators and Dialogue Facilitators in Ukraine: Core Methods}

Distinction or similarities between mediation and dialogue facilitation as methods of conflict resolution present a food for heated debates by practitioners in Ukraine and elsewhere in the world.

In the field of mediation, "facilitative mediation" 30 is considered a mainstream mediation model not only in Ukraine but also all over the world. In short, the main goal of a mediator in this model is to facilitate settlement process by eliciting the interests of the conflict parties that underlie their initial positions in negotiations. The mediator should be perceived as a neutral and impartial professional who neither makes a decision, nor evaluates the merits of the case. The procedural framework of facilitative mediation usually includes a first joint meeting of the parties, individual caucuses, and concluding joint meeting to sign an agreement, which is the most desirable outcome of the process. Despite critique, ${ }^{31}$ this model continues to serve as an aspirational ideal for mediators worldwide. ${ }^{32}$

Ukrainian mediators were also keen to establish their professional identity based on facilitative mediation model. From the outset, they decided to avoid translating the term "mediation" into the Ukrainian language and consciously relied on its anglicized form: "mediatsiia". Facilitative mediation model soon became "the classic mediation model" for Ukrainian mediators that largely excluded differing styles of mediation such as transformative ${ }^{33}$ or evaluative mediation. ${ }^{34}$ Facilitative mediation has been legitimized as a mainstream model in the draft law on mediation No. 3665 , which was voted by the Parliament on the first reading in

29 Interview with Ukrainian dialogue facilitator, Kyiv, January 26, 2017; Focus-group discussion with Ukrainian dialogue facilitators, Kyiv, June 1, 2016.

Facilitative mediation model admittedly derives from an interest-based approach to negotiations developed by Fisher and Ury. See, Roger Fisher, William L Ury, and Bruce Patton, Getting to Yes: Negotiating Agreement without Giving in (New York: Penguin, 2011).

$31 \quad$ Kenneth M Roberts, "Mediating the Evaluative-Facilitative Debate: Why Both Parties Are Wrong and a Proposal for Settlement," Loyola University Chicago Law Journal 39 (2007).

Nancy Erbe, "Global Popularity and Promise of Facilitative Adr," Temple International \& Comparative Law Journal 18 (2004); Carole J Brown, "Facillitative Mediation: The Classic Approach Retains Its Appeal," Pepperdine Dispute Resolution Law Journal 4.2 (2003).

33 Robert A Baruch Bush and Joseph P Folger, The Promise of Mediation: The Transformative Approach to Conflict: (San Francisco: John Wiley \& Sons, 2004).

34 Leonard Riskin, "Understanding Mediators' Orientations, Strategies, and Techniques: A Grid for the Perplexed," Harvard Negotiation Law Review 1.7 (1997). 
November 2016. The draft contains provisions that the decisions on the merits are made solely by the parties; the mediator has no right to solve the conflict of the parties; the mediator can advise parties exclusively on procedural matters and matters concerning the settlement agreement; finally, mediator is expressly prohibited to evaluate parties' behavior and positions unless they agree on such an evaluation in writing. ${ }^{35}$ These draft provisions give a ground to believe that the mainstream Ukrainian mediation community remains faithful to the purity of facilitative mediation. This reliance on a single model of professional practice ensured rather quick and consistent professional identity formation and, at the same time, left the doors open to some controlled evaluative practices.

In contrast to mediators, establishing distinct professional identity for dialogue facilitators turned out to be much more challenging. Indeed, discussions about "what dialogue is and is not" were formally and informally present at all events that the author has attended as a part of the fieldwork. There is no agreement in the academic literature on the precise definition of dialogue; dialogue facilitation as a process is often defined through a reference to mediation. ${ }^{36}$ Therefore, the facilitators' search for the professional borders inevitably draws upon differences of their practices from mediation practices. The task is not an easy one, as mediation itself remains generally an unknown dispute resolution method in Ukraine, let alone dialogue facilitation. While mediation was initially applied in domestic contexts of civil, commercial, family, employment, and similar disputes, dialogue facilitation is applied in a very different context of complex sociopolitical multi-layered inter-group conflicts involving the use of force and violence. ${ }^{37}$ Given the differences in contexts, it is not surprising that the process and the skills of dialogue facilitation depart from the classic facilitative mediation model.

The points of departure, first of all, can be seen through analysis of the aims of these processes. While mediation, in its mainstream form, is clearly aimed at resolution of the concrete dispute or issues between two or more disputing parties ("problem-solving"), dialogue can have twofold aim - "problem-solving" as well as "trust- and understanding-building." For example, the OSCE Reference Guide suggests that "although dialogues can lead to very concrete decisions and actions, the primary aim is not to reach a specific settlement, but to gain a better understanding of the different perspectives involved in a conflict." ${ }^{38}$ Thus, while building trust and understanding between participants of dialogue is indispensable feature of the dialogue facilitation process, resolution or decision-making remains its possible but not required consequence.

35 Articles 6-8 of the Draft Law on Mediation No. 3665.

36 Amanda E. Feller and Kelly K. Ryan, "Definition, Necessity, and Nansen: Efficacy of Dialogue in Peacebuilding," Conflict Resolution Quarterly 29.4 (2012); Norbert Ropers, "From Resolution to Transformation: The Role of Dialogue Projects," in Berghof Handbook of Conflict Transformation, ed. Beatrix Austin (Berghof Research Center for Constructive Conflict Management, 2004). John Paul Lederach, Building Peace: Sustainable Reconciliation in Divided Societies, (1997); Preparing for Peace: Conflict Transformation across Cultures, (Syracuse University Press, 1995); Johan Galtung, Peace by Peaceful Means, (Sage, 1996). "Mediation and Dialogue Facilitation in the OSCE: Reference Guide," 10, accessed December 20, 2017, http://www.osce.org/secretariat/126646?download=true. 
Furthermore, in contrast to mediation that relies primarily on one model of "facilitative mediation," dialogue facilitation involves multiple methodologies. In practice, Ukrainian facilitators have identified at least seven approaches that have been applied in Ukraine so far: Non-Violent Communication, Alternatives to Violence, Process-Oriented Psychology, Technology of Participation, Round-Tables, Restorative Circles, and Theatre for Dialogue. ${ }^{39}$ Interviewees in this study also suggested that mediation itself can be viewed as one of the instruments of dialogue. ${ }^{40}$ While these eclectic methodologies derive from common ideas about importance of respect for human dignity, inclusion, safe communication, mutual understanding, empowerment and recognition of the conflict parties, they still are very diverse and provide rather unstable base for professional identity of dialogue facilitators.

This research suggests that discussions about the core methods of dialogue facilitation reflect the pain of professional growth and self-identification of this professional community. A remarkable attempt to produce a common understanding of dialogue was made by the first online course on dialogues which was convened by the National Association of Mediators of Ukraine (NAMU) and supported by the OSCE PCU. ${ }^{41}$ NAMU managed to unite leading Ukrainian NGOs active in the dialogue facilitation field as co-authors of the online course. Apart from informational and educational impact of this course, it became a platform for self-reflection and identity-formation of Ukrainian dialogue facilitators as a professional community.

The further work on a common vision of dialogue is currently led by the Ukrainian Institute for Peace and Common Ground, and it is expected that a joint statement or standards of dialogue practice will be released in early 2018.The draft standards suggest distinguishing "dialogue" and "facilitated dialogue." The facilitated dialogue is defined as a specially prepared group process that is conducted with the help of facilitator and aims at trust-building and decision making regarding joint actions or resolution of the conflict and allows an equal opportunity for participants to express themselves. ${ }^{42}$ In the author's knowledge, this is the first time when local community, and not international experts, tells the outside world what they consider to be "dialogue" and "best practices" of dialogue facilitation.

Thus, while Ukrainian mediators have achieved consensus regarding facilitative mediation model as a mainstream standard for their practice, dialogue facilitators are faced with the dilemma of finding a right balance between variety of methodological approaches to their practice and the need to assure at least some uniformity and quality standards in their practice. http://ukraine.dialoguesupport.org/en/reports. 


\section{Ideologies and Societal Roles of Mediators and Dialogue Facilitators: Service Providers or Agents of Change?}

Based on the analysis of personal motivations and value-orientations of Ukrainian mediators and dialogue facilitators, this research has identified two types of societal roles or ideologies of these professional communities that can be referred to as "service provision" and "societal transformation". This finding is in line with the research on ideologies of mediators in the US. For example, Harrington and Merry have studied community mediation programs and concluded that they were dominated by ideologies of "delivery of dispute resolution services," "social transformation," and "personal growth and development." 43 Within Ukrainian context, personal growth and development was equally important for all mediators and dialogue facilitators while the differences emerged with respect to "service provision" and "societal transformation" ideologies.

The first set of ideologies refers to service provision. Mediators and dialogue facilitators who are more oriented towards professionalization and service provision see mediation and facilitation as a potential profession. They are eager to generate a nationwide demand for their services to support commercialized practice and full-time careers; are concerned about institutionalizing, legitimizing, and legal regulation of their practices within state structures. This research revealed that Ukrainian mediators see themselves more as service providers and therefore they invest substantial efforts into drafting and lobbying for legislation, developing accreditation for training programs and professional standards such as the Codes of Ethics. In contrast, dialogue facilitators have consciously omitted entrance barriers to their professional practice and will regulate only some issues of conduct of facilitators. ${ }^{44}$

The second set of ideologies - society-oriented or societal transformation ideology derives from the core values of mediation and dialogue such as inclusivity, voluntary participation, empowerment and recognition of all participants. Based on these values, trust-building, settlement or decision-making in mediation and dialogue become possible only when participants possess decision-making power and free will to do so. This highlights the need for the enhanced responsibility of individuals for making decisions regarding matters of their lives and departure from the patrimonialism of the Soviet legacy. Therefore, mediation and dialogue are viewed as important tools of deliberative democracy that can contribute to uniting Ukrainians as a political nation and ultimately to democratic societal transformations. Consequently, practices of mediation and dialogue should be integrated into societal fabric at all levels - from schools, local communities, workplace and families, to courts, local authorities, central government and the parliament. This societal transformation ideology was identifiable within mediators as well as dialogue facilitators, yet they were interpreted in slightly different ways.

Dialogue facilitators suggested that to achieve meaningful societal changes, they should play more active role in the civil society initiatives, beyond just facilitation of dialogue sessions.

43 Christine B Harrington and Sally Engle Merry, "Ideological Production: The Making of Community Mediation," Law and Society Review (1988).

44 Draft Dialogue Standards, Institute for Peace and Common Ground, http://ipcg.org.ua/ novosti/299.html. 
For example, Odesa Regional Mediation Group has developed their "Odesa Model of Dialogue" where facilitators and other persons were entrusted with various functions and roles including multiplicators (those who take care of contacts with the authorities and the opinion leaders within a community and spread the word about dialogue as a tool of trust-building and participatory decision-making); analysts(those who monitor situation on the ground and give a signal to initiate a dialogue when they "smell the smoke"); organizers (those who take care of logistics of dialogue preparation and facilitated meetings); dialogue facilitators (those who facilitate the dialogue sessions); and experts (those who can offer expert advice regarding the subject matter of the issues in the dialogue sessions). This approach to dialogue facilitation allows facilitators to act as agents of change, to monitor societal situation on the ground, and to initiate dialogue when such an intervention is required, as well as to support civic activism that results from facilitated dialogues. Furthermore, dialogue facilitators plan certain concerted actions to lobby the government in order to change current policies towards more peace, reconciliation and dialogue approaches in Ukraine. In this way dialogue facilitation becomes more institutionalized and engraved into societal fabric and can offer some routes to bottom-up political changes.

In contrast, mediators connect to the wider societal transformation ideas through their work towards pro-settlement cultural shift within legal community and state structures. For example, mediators cooperate with the Ministry of Social Policy to develop schemes of mediation in family cases involving divorces and children and to raise public awareness about mediation as a tool of out-of-court dispute resolution. Many interviewees in this study as well as participants in the strategic planning sessions revealed that an ultimate goal of their mediation organizations was "raising a culture of peaceful conflict resolution in Ukraine" that in turn can trigger selfsustainable commercial mediation market. ${ }^{45}$

Thus, dialogue facilitators see societal transformation as an ultimate goal of their activities while mediators treat societal transformation as a tool to increase demand in mediation services.

To conclude, both "service provision" and "societal transformation" ideologies of Ukrainian mediation and dialogue facilitation communities seem to be closely interrelated and supportive of each other. Despite some internal tensions outlined above, both sets of ideologies connect to the wider ideologies of Ukrainian civil society and potentially can contribute to democratic processes within Ukraine.

\section{Challenges and Opportunities of the 2014 Crisis}

The 2014 Euromaidan protests, the annexation of Crimea by Russia and armed conflict in Eastern Ukraine posed a threat "to the wider European security order of a greater magnitude than anything since the end of the Cold War". ${ }^{46}$ The conflict has received a mixed response from the international community, which applies both types of measures: economic sanctions against

45 Interview with Ukrainian mediator, Lviv, June 10, 2016. See also, Zvenyslava Novakivska, Rezultaty strategichnoyi sesiyi po planuvanniu rozvytku seredovyscha mediatoriv do 2020 [Results of the Strategic Session on Planning of Mediation Development 2020] (OSCE, 2017).

46 Roy Allison, “Russian 'Deniable' Intervention in Ukraine: How and Why Russia Broke the Rules,” International Affairs 9o.6 (2014): 1255 . 
Russia and military empowerment of Ukraine, on the one hand; and peace negotiations, multitrack peacebuilding and promotion of mediation and dialogue, on the other hand. Similarly, the Ukrainian government is carrying out a costly and prolonged military campaign in the East of the country, and simultaneously responds to the international pressure toward reconciliation and peacebuilding. Mixed conflict response has imprinted at the society as "neither war, nor peace" or a "societal schizophrenia." ${ }^{47}$ Nearly all interviewees in this study emphasized increasing polarization and fragmentation of the Ukrainian society at all levels which is further supported by mass media and political discourse. This thorny political and societal context offered challenges as well as some opportunities for Ukrainian mediators and dialogue facilitators after 2014.

The 2014 crisis has accelerated development of mediation as a part of the judicial reform in Ukraine. Popular perceptions of Ukrainian courts as a corrupt system and demands for "fair justice for all" were among the driving forces of the Euromaidan. In the aftermath of the protests, court reform was recognized as a priority both by the new Ukrainian Government and the international community. In turn, court reform was considered to benefit from the introduction of mediation as a tool that helps to improve access to justice. Therefore, in contrast to previous waves of reforms, the EU Commission, the World Bank and the International Monetary Fund were more explicit in requiring mediation. This requirement was reflected in several policy documents of Ukrainian government. ${ }^{48}$ Furthermore, pressures from the international community prompted amendments to the Constitution of Ukraine that expressly allowed mandatory pre-trial dispute resolution mechanisms, including mediation. This gave a green light to mandatory court mediation if someday legislators would deem it necessary. ${ }^{49}$ As a corollary of this policy, some international donor organizations have also increased funding for projects on various aspects of mediation integration within court system (training of judges, drafting of mediation legislation, mediation components within legal education, etc.).50

Despite these developments, compared to other areas of court reform such as judicial independence and fight against corruption, mediation has not yet acquired primary importance in Ukraine. Therefore, the main piece of mediation legislation — the law on mediation - is still not adopted by the Parliament.

47 Interview with Ukrainian donor, Kyiv, June 30, 2017.

48 Decree No. 276/2015 of the President of Ukraine of May 20, 2015 "Strategy of reform of court system, court procedures and related legal institutions in 2015-2020", accessed December 20, 2017, http:// zakon4.rada.gov.ua/laws/show/276/2015; Decree No. 1406-p of the Cabinet of Ministers of Ukraine of December 16, 2015 "Action plan on implementation of the best practices of high quality and efficient regulation by the World Bank Group rating "Doing Business" (as amended), accessed December 20, 2017, http://zakon1.rada.gov.ua/laws/show/1406-2015-\%D 1\%80; Resolution of the Cabinet of Ministers of Ukraine No. 418-p of 27 May 2015 "On approval of the Plan of priority actions of the government of Ukraine for 2016", accessed December 20, 2017, http://zakon5.rada.gov.ua/laws/ show/418-2016-\%D 1\%8o/paran6\#ng.

49 Article 124 of the Constitution of Ukraine. See Law of Ukraine No. 1401-VIII "On Amendments to the Constitution of Ukraine" of June 2, 2016, accessed December 20, 2017, http://zakon5.rada.gov.ua/ laws/show/1401-19. Interview with representative of the international donor, June 8, 2016. 
Similar to mediators, dialogue facilitators have to respond to post-Euromaidan challenges and opportunities. According to dialogue facilitators interviewed in this study, the main impetus for their professional community is connected to the armed conflict in Eastern Ukraine that alleviated European security concerns and prompted a substantial funding for peacebuilding initiatives at civil society level (track III peacebuilding). ${ }^{51}$ However, increased funding has produced a side-effect of a "crowded field" of peacemakers in Ukraine with fierce funding competition among local and international organizations, and within these groups. An international dialogue expert has illustrated this trend in the following way:

So, the main problem I see is the competition, which ironically has been exacerbated by the massive needs. And it's the usual competition for resources and for grants, for financial support. There is also the competition for prestige and almost a need to monopolize certain space to be the one and only that the international community goes to (UN, OSCE, donors) as well as local authorities. Fortunately, that small group of older facilitators maintains communication and in several instances even cooperation and I think that this has to be supported.

Thus, increased bottom-up support and funding have accelerated internal tensions within dialogue facilitation community and more cooperation seems to be vital for further survival and development of the community.

At the same time, we observe top-down international pressures aimed at national reconciliation and transformation of Ukraine towards more tolerant and inclusive society. For example, "Ukraine Recovery and Peacebuilding Assessment" by the United Nations, European Union and the World Bank recommended Ukrainian government and civil society actors to promote social cohesion and a culture of tolerance through dialogue and civic participation with full inclusion of women, youth, and any minority groups. ${ }^{52}$ These aims were reflected in the policy documents of the Ukrainian government. ${ }^{53}$ For example, the Action Plan of the Ministry of Temporary Occupied Territories and IDPs expressly spells out the task to promote dialogues

$5^{1} \quad$ Focus-group discussion with Ukrainian dialogue facilitators, Kyiv, June 1, 2016.

$5^{2}$ UN/EU/World Bank “Ukraine Recovery and Peacebuilding Assessment," accessed December 20, 2017, http://www.un.org.ua/en/publications-and-reports/un-in-ukraine-publications/3738-ukrainerecovery-and-peacebuilding-plan-volume-2.

Ministry of Temporary Occupied Territories of Ukraine, Draft State Program on Recovery and Peacebuilding in Eastern Regions of Ukraine, accessed December 20, 2017, http://mtot.gov.ua/ uvaga-ogolosheno-provedennya-gromadskyh-publichnyh-obgovoren-proektu-derzhavnoyi-tsilovoyiprogramy-vidnovlennya-ta-rozbudovy-myru-v-shidnyh-regionah-ukrayiny/; Cabinet of Ministers of Ukraine, National Action Plan "On Implementation of United Nations Security Council Resolution 1325 “Women, Peace and Security”, accessed December 20, 2017, http://zakon2.rada.gov.ua/laws/ show/113-2016-\%D 1\%8o/print1493904687523518\#n11. 
with people from the territories currently non-controlled by the Ukrainian government (crosscontact-line dialogues).54

Given the increasing polarization of Ukrainian society and divisions on the matter of the status of Donbas and current armed conflict, the above policies of international community towards peacebuilding and reconciliation have met certain resistance by some parts of Ukrainian civil society which is unsurprisingly as divided by discourses of peace and war as the rest of the society. The tensions between the professional community of mediators and facilitators vis-à-vis so-called "patriotically-oriented" segments of civil society became obvious in the declaration of several women's NGOs entitled "Under the Cover of Women and Peace." 55 This public statement accused dialogue initiatives between Ukrainian and Russian civil society of "the psychological disarmament of Ukrainians during the war, manipulation with the concepts and imposition of guilt and responsibility for the situation upon Ukrainians under the cover of women and human rights organizations, which are sponsored by international donors, international organizations or Russia." Petitioners also asked to "establish a Parliamentary Commission to investigate activity of peacebuilding initiatives that are carried out under cover of women and human rights movements." This clash demonstrated a potentially destructive trend that requires more research to identify its root causes and to assist the international community and the Ukrainian mediators and facilitators to develop strategies that will unite rather than divide Ukrainian civil society on the matter of peacebuilding and reconciliation.

Thus, the 2014 crisis offered opportunities such as pressures for greater use of mediation and dialogue and increased funding for these activities. While the pressure of the international community towards institutionalized mediation does not seem to be sufficient yet to trigger major societal changes, the pressure in the area of dialogue and peacebuilding is stronger but might also trigger some negative consequences.

\section{Conclusion}

Based on the findings of empirical research, this article has demonstrated that the role of civil society in peacebuilding within post-Euromaidan Ukrainian societal context is determined by the presence of a self-organized, self-aware and skilled local professional community of mediators and dialogue facilitators. This renders, among other factors, the current armed conflict in Ukraine unique. Being a part of the wider civil society, Ukrainian professional peacemakers - mediators and dialogue facilitators — can potentially play a leading role in peacebuilding and reconciliation

54 Ministry of Temporary Occupied Territories of Ukraine, Action Plan of January 11, 2017 "On implementation of certain fundamentals of domestic policy regarding certain areas of Donetsk and Luhansk regions, where state authorities temporarily do not exercise their power", accessed December 20, 2017, http://zakon2.rada.gov.ua/laws/show/8-2017-\%D 1\%80.

55 NGO Statement of March 5, 2017, "Under cover of peace and women", accessed December 20, 2017, http://www.ukrpress.info/2017/o3/o5/pid-prikrittyam-miru-y-zhinok-zayava-nou/. Although, according to interviewees in this study, this clash between various NGOs was admittedly triggered by interpersonal relations of their leaders, it still demonstrates the deep divide of Ukrainian civil society on the peacebuilding and reconciliation issues. 
processes. This research is a first attempt to attract attention of scholars and practitioners to this phenomenon.

To advance this conclusion, the article has outlined the major characteristics of the two professional communities. Mediators present a professional community with more than 3,000 people trained in mediation since mid-199o-s, and include around twenty national and regional mediation providers and training centers, united under an umbrella organization - the National Association of Mediators. Ukrainian mediators were quite successful in the establishing their professional identity based on a single model of mediation practice-facilitative mediation. This reliance on a single model of professional practice ensured rather quick and consistent professional identity formation, at the same time, left the doors open to some controlled evaluative practices. Although the mediation community still faces many challenges such as the development of a demand for mediation services, the lobbying for the law on mediation, and the integration of mediation within the court system, ${ }^{56}$ they present a highly competent and vibrant professional community that is on a track of self-regulation and cooperation with all other stakeholders.

Dialogue facilitators in Ukraine became visible only since 2014, having to simultaneously establish themselves as a professional community and to respond to the challenges of the crisis. This research has identified around 20 Ukrainian organizations active in dialogue facilitation. Since 2014, dialogue facilitators initiated or became involved in various dialogue initiatives connected to the armed conflict in the Eastern Ukraine. In contrast to mediators who rely on a single mediation model (facilitative mediation), dialogue facilitators are still searching for their professional identity embracing the whole variety of dispute resolution, communication and decision-making methods and tools. It is expected that Ukrainian dialogue facilitators will soon offer their vision of dialogue and its main principles in a written statement. This research suggests that this is the first time when local professional community of dialogue facilitators independently tells their international colleagues and the government how they see the best practices of dialogues and how to implement them during an on-going armed conflict.

In terms of societal roles, this research has identified two competing sets of ideologies within both communities. While most mediators see themselves as service providers and aim at commercialization and professionalization of their services, dialogue facilitators are more aspired by their role as agents of societal changes. At the same time, both orientations are presents in both communities, albeit in different proportions. Mediators still promote cultural shift towards peaceful dispute resolution in Ukraine, and dialogue facilitators increase professionalization of their practice.

The 2014 crisis has altered the dynamics of mediation and dialogue development in Ukraine. The armed conflict has amplified socio-political uncertainties and polarization in Ukraine and complicated the process of popular acceptance of mediation and dialogue. At the same time, the crisis has provided some opportunities for mediation and dialogue facilitation. In the aftermath of Euromaidan and during the ongoing armed conflict in the Eastern Ukraine, both professional

56 For analysis of mediation integration, See Tatiana Kyselova, Integration of Mediation into Court System of Ukraine: Policy Paper (Council of Europe, 2016), accessed December 20, 2017, http://ssrn. com/abstract $=3054519$. 
communities have to react to increased international involvement in various aspects of their activities. This research reveals that international community has noticeably increased funding for mediation and dialogue projects after 2014, and has intensified formal and informal top-down pressure for a greater use of mediation and dialogue in Ukraine. While this pressure does not seem to be sufficient to trigger major changes in the field of mediation yet, the pressure in the area of dialogue facilitation is apparently stronger and capable to push positive changes, as well as some negative consequences such as funding competition between NGOs or ideological clashes between "professional peacemakers" and those segments of civil society who primarily aim at the fight against Russian aggression. These challenges, if remain unrecognized by researchers, professional communities and stakeholders, may potentially cause divisions within civil society and contribute to further societal polarization.

Overall, mediators and dialogue facilitators present an important organized group of Ukrainian civil society that has possessed context-specific conflict expertise and training capacities as well as the practical experience of dealing with various types of conflicts on the ground. This article suggests that better results can be achieved by the international community relying on the expertise of Ukrainian mediators and facilitators in accordance with the principle of local ownership of dialogue and mediation initiatives. ${ }^{57}$ However, capacities of these professional communities should not be overestimated. Dialogue and mediation will not happen on their own, even if international donors invest in initial training of mediators and dialogue facilitators. According to interviewees in this study, mediators and facilitators need substantial support in organizational capacity-building, including financial support to those who mediate or facilitate on the ground, schemes of their mentoring and supervision, and establishment of self-sustainable mechanisms that would connect mediators and facilitators to their end-users. 58

\section{Bibliography}

Allison, Roy. "Russian 'Deniable’ Intervention in Ukraine: How and Why Russia Broke the Rules.” International Affairs 9o.6 (2014): 1255-97.

Brown, Carole J. "Facillitative Mediation: The Classic Approach Retains Its Appeal." Pepperdine Dispute Resolution Law Journal 4.2 (2003): 279-95.

Bush, Robert A. Baruch, and Joseph P. Folger. The Promise of Mediation: The Transformative Approach to Conflict. San Francisco: John Wiley \& Sons, 2004.

Carothers, Thomas, and William Barndt. "Civil Society." Foreign Policy 117 (2000): 18-29.

Global Protection Cluster, Peacebuilding and Reconciliation in Ukraine. "Guidance Note," (2016). Accessed December 20, 2017, http://www.globalprotectioncluster.org/_assets/files/field_ protection_clusters/Ukraine/thematic-updates/peacebuilding_reconciliation_guidance _ note_en.pdf.

57 For national ownership principle, See United Nations Guidance for Effective Mediation, accessed December 20, 2017, http://peacemaker.un.org/sites/peacemaker.un.org/files/ GuidanceEffectiveMediation_UNDPA2012\%28english\%29_o.pdf. 
Cristescu, Roxana, and Denis Matveev. The Challenge of Inclusiveness in the Peace Processes in Ukraine. Civil Society Dialogue Network, 2017.

De Palo, G, L D'Urso, M Trevor, B Branon, R Canessa, B Cawyer, and R Florence. "Rebooting the Mediation Directive: Assessing the Limited Impact of Its Implementation and Proposing Measures to Increase the Number of Mediations in the EU." Brussels: DG for Internal Policies, 2014.

De Palo, Giuseppe, and Mary Trevor. Eu Mediation Law and Practice. Oxford: OUP 2012.

Editorial. "Mediatsia kak sposob yevropeizatsii strany [Mediation as a Means of Europeanization of Ukraine]," Investytsiyna Gazeta, April 13, 2013.

Erbe, Nancy. "Global Popularity and Promise of Facilitative Adr" Temple International \& Comparative Law Journal 18 (2004): 343.

Feller, Amanda E., and Kelly K Ryan. "Definition, Necessity, and Nansen: Efficacy of Dialogue in Peacebuilding." Conflict Resolution Quarterly 29.4 (2012): 351-80.

Fisher, Roger, William L. Ury, and Bruce Patton. Getting to Yes: Negotiating Agreement without Giving In. New York: Penguin, 2011.

Fuller, Lon L. "Mediation —Its Forms and Functions." South California Law Review 44 (1971): 305. Galtung, Johan. Peace by Peaceful Means. London: Sage, 1996.

Harrington, Christine B., and Sally Engle Merry. "Ideological Production: The Making of Community Mediation." Law and Society Review (1988): 709-35.

Hendley, Kathryn. "What If You Build It and No One Comes? The Introduction of Mediation to Russia." Cardozo Journal of Conflict Resolution. 14 (2013): 727-58.

Krupelnitsky, Vitalii. "Mediatsia yak yavysche yevropeiskykh pravovidnosyn [Mediation as a Phenomenon of European Legal Relations]," Pravo Today October 25, 2011, Accessed December 20, 2017, http://pravotoday.in.ua/ua/press-center/publications/pub-681/.

Kyselova, Tatiana. "Dualism of Ukrainian Commercial Courts: Exploratory Study." Hague Journal on the Rule of Law 6.02 (2014): 178-201.

Kyselova, Tatiana. Integration of Mediation into Court System of Ukraine: Policy Paper. Council of Europe, 2016.

Kyselova, Tatiana. Mediation Organizations in Ukraine: Short Guide 2017. Accessed December 20, 2017, https://www.academia.edu/32378787/Mediation_Organizations_in_Ukraine_Short_ Guide_2017.

Kyselova, Tatiana and Julia von Dobeneck, Track III Dialogues in Ukraine: Major Patterns and Resulting Risks. 2017.

Lederach, John Paul. Building Peace: Sustainable Reconciliation in Divided Societies. 1997.

Lederach, John Paul. Preparing for Peace: Conflict Transformation across Cultures. Syracuse: Syracuse University Press, 1995 .

Mapping of Dialogue Initiatives to Resolve the Conflict in Ukraine. Kyiv: International Center for Policy Studies, 2015. Accessed December 20, 2017, http://icps.com.ua/assets/uploads/files/ mapping_of_dialogue_initiatives_eng_pdf.

McGuinness, Margaret E. "Women as Architects of Peace: Gender and the Resolution of Armed Conflict." Michigan State Journal of Internationall Law. 15 (2007): 63.

Mehmel, Friedrich-Joachim, and Frans van Arem. Court-Bounded and Commercial Mediation - a Pilot Project in Ukraine: A Story of Success. Kyiv: Council of Europe, 2011. 
Menkel-Meadow, Carrie. "Mothers and Fathers of Invention: The Intellectual Founders of Adr." Ohio State Journal on Dispute Resolution 16 (2000): 1.

Menkel-Meadow, Carrie. "Variations in the Uptake of and Resistance to Mediation Outside of the United States." In Contemporary Issues in International Arbitration and Mediation: The Fordham Papers 2014, edited by Arthur Rovine, 189-221. Leiden and Boston: Brill, 2015.

Merry, Sally Engle. "Moving Beyound Ideology Critique to the Analysis of Practice." Law \& Social Inquiry 27.3 (2002): 6o9-12.

Mubashir, Mir, Engjellushe Morina, and Luxshi Vimalarajah. Osce Support to Insider Mediation: Strenghtening Mediation Capacities, Networking and Complementarity. OSCE, 2016.

Novakivska, Zvenyslava. Rezultaty strategichnoi sesii po planuvanniu rozvytku seredovyscha mediatoriv do 2020 [Results of the Strategic Session on Planning of Mediation Development 2020] OSCE, 2017.

Organization for Security and Co-operation in Europe, Special Monitoring Mission. Civil Society in the Ukrainian Crisis: Thematic Report. 2015. available at http://www.osce.org/ukrainesmm/141046?download=true.

Paffenholz, Thania. "International Peacebuilding Goes Local: Analysing Lederach's Conflict Transformation Theory and Its Ambivalent Encounter with 20 Years of Practice." Peacebuilding 2.1 (2014): 11-27.

Pylypiv, Natallia. "Vidnovne pravosuddia v Ukraini: rezultaty ta perspektyvy [Restorative Justice in Ukraine: Results and Prospects]," Vidnovne Pravosuddia v Ukraini 17.3-4 (2011): 87-99.

Riskin, Leonard. “Understanding Mediators' Orientations, Strategies, and Techniques: A Grid for the Perplexed." Harvard Negotiation Law Review 1.7 (1997): 7-51.

Roberts, Kenneth M. "Mediating the Evaluative-Facilitative Debate: Why Both Parties Are Wrong and a Proposal for Settlement." Loyola University Chicago Law Journal 39 (2007): 187.

Ropers, Norbert "From Resolution to Transformation: The Role of Dialogue Projects," in Berghof Handbook of Conflict Transformation, ed. Beatrix Austin (BerghofResearch Center for Constructive ConflictManagement, 2004).

Special Monitoring Mission Organization for Security and Co-operation in Europe, Civil Society in the Ukrainian Crisis: Thematic Report, (2015). Accessed December 20, 2017, http://www. osce.org/ukraine-smm/141046?download=true.

Vasylchak, S.V., and L. V. Kutas. "Mediation as a Method of Civilized Resolution of Corporate Disputes." Scientific Journal NLTU Ukraine 20.14 (2010): 133-37.

Vasyliev, Yegor. "Alternative Dispute Resolution in a Global Perspective: Legal, Political and Cultural Factors in Introducing Mediation to Post-Soviet Ukraine." SSRN eLibrary June 5, 2013 (2013).

Yelnyk, Pavlo. "Ugoda pro assotsiatsiyu Ukraina-YeS:Yevropeiski mekhanismy vyrishennia sporiv [EU-Ukraine Association Agreement: European Mechanisms of Dispute Resolution]," Kyiv Mediation Center. Accessed December 20, 2017, http://medyacia.com/page102575.html.

Zaretskaia, Irina. "Put k soglasiyu ili peregovory bez porazheniia [Getting to Yes or Negotiations without Giving In]," Yur Liga (2012). Accessed December 20, 2017, http://jurliga.ligazakon. ua/yurtv_detail/211. 
(2)

Tatiana Kyselova is an Associate Professor in the Faculty of Law at Kyiv-Mohyla Academy in Kyiv, Ukraine and a visiting teaching fellow at Queen Mary, University of London. In 2015-2017 she was a Marie Curie/COFUND postdoctoral fellow at University of Turin, Italy. She received her LLM from the London School of Economics and Political Science, kandydat nauk from the Ukrainian National Academy of Science and a DPhil from University of Oxford. She specializes in socio-legal studies, conflict resolution, alternative dispute resolution, and post-Soviet transition. 